\title{
E-Rubric Kerja Ilmiah dengan Menggunakan Model Pembelajaran Inkuiri Terhadap Efektifitas Proses Pembelajaran
}

\author{
Muhammad Nur Hudha ${ }^{1}$, Sudi Dul Aji ${ }^{2}$, Yohana Susana Wolla Baga ${ }^{3}$, Arief Rahman Hakim ${ }^{4}$ \\ Universitas Kanjuruhan Malang \\ muhammadnurhudha@unikama.ac.id
}

\begin{abstract}
Abstrak
Rubrik merupakan suatu perangkat penilaian yang cocok digunakan dalam penilaian bertingkat dan bertahap. Pengembangan e-rubric kerja ilmiah dengan menggunakan model inkuiri sangat cocok untuk mengatasi efisiensi proses penilaian kerja ilmiah siswa. Penelitian ini merupakan jenis penelitian deskriptif. Instrumen yang digunakan dalam penelitian ini adalah menggunakan observasi, wawancara, dan angket. Hasil dari penelitian ini adalah pembelajaran menggunakan model pembelajaran inkuiri berbantuan aplikasi e-rubric sangat efektif dalam menilai kerja ilmiah siswa selama proses pembelajaran berlangsung.
\end{abstract}

Kata kunci: e-rubric, inkuiri, kerja ilmiah

\begin{abstract}
The rubric is a function of the device used in multilevel and gradual measurements. The development of scientific work e-rubrics using the inquiry model is very suitable for the assessment process. This research is a type of descriptive research. The instruments used in this study were measurements, interviews, and questionnaires. The results of this study are learning using the assisted inquiry learning model application of e-rubric which is very effective in studying student learning outcomes during the learning process.
\end{abstract}

Keywords: e-rubric, inquiry, scientific work

\section{PENDAHULUAN}

Rubrik merupakan suatu perangkat penilaian yang menggambarkan kriteria yang diinginkan guru dalam menilai atau memberi tingkatan dari hasil pekerjaan siswa (Dickinson \& Adams, 2017). Rubrik digunakan oleh guru untuk mengevaluasi lebih dari sekedar deskripsi dari suatu evaluasi dan (yaitu, program, proyek atau kebijakan yang akan dievaluasi) untuk menentukan kualitas serta keberhasilan evaluasi siswa.

Rubrik berfungsi untuk membantu penilaian profesional guru (Menéndez-Varela \& Gregori-Giralt，2018); (Menéndez-Varela \&
Gregori-Giralt, 2018). Penilaian rubrik sangat cocok digunakan dalam penilaian bertingkat dan bertahap. Namun, masalah bagi para guru yang tertarik menggunakan rubrik adalah literatur yang berkaitan dengan pengembangan rubrik belum banyak yang tersebar (Menéndez-Varela \& Gregori-Giralt, 2018).

Proses pembelajaran Fisika sangat cocok menggunakan rubrik dalam proses penilaiannya (Aji, Hudha, Huda, Nandiyanto, \& Abdullah, 2018); (Hudha, Aji, \& Huda, 2018). Fisika merupakan bagian dari Ilmu Pengetahuan Alam, yang berkaitan dengan cara mencari tahu tentang alam secara sistematis berupa 
penemuan, fakta, konsep-konsep atau prinsipprinsip serta prospek pengembangan lebih lanjut dalam menerapkan pengetahuan di dalam kehidupan sehari-hari. Fisika merupakan proses dan produk. Proses artinya prosedur untuk menemukan produk fisika (fakta, konsep, prinsip, teori atau hukum) yang dilakukan melalui langkah-langkah ilmiah. Tujuan pembelajaran fisika adalah agar siswa dapat menguasai berbagai konsep dan prinsip fisika untuk dapat mengembangkan pengetahuan, keterampilan, dan sikap sehingga dapat diterapkan dalam kehidupan sehari-hari (Aji \& Hudha, 2015).

Fisika mengkaji objek-objek telaahnya yang berupa benda-benda serta peristiwa alam menggunakan prosedur yang baku yang biasa disebut metode/proses ilmiah. Proses ilmiah merupakan keseluruhan keterampilan ilmiah yang terarah (baik kognitif, afektif maupun psikomotor) yang dapat digunakan untuk menemukan fakta, membangun konsep dan teori dengan keterampilan intelektual dan sikap kerja ilmiah siswa sendiri melalui proses belajar mengajar dikelas sehingga siswa terlibat langsung dalam kegiatan ilmiah (Pratama, Nurris Septa; Istiyono, 2015).

Proses pembelajaran fisika tidak hanya mengutamakan aspek kognitif siswa, tetapi juga mengutamakan aspek psikomotorik. Aspek atau ranah psikomotorik merupakan suatu aspek kompetensi melakukan kegiatan yang melibatkan anggota badan serta kompetensi yang berkaitan dengan gerak fisik (motorik) yang terdiri dari gerakan refleks, keterampilan gerakan dasar, keterampilan kompleks, kemampuan persepual, ketepatan, serta ekspresif dan interperatif. Kategori yang termasuk dalam aspek ini adalah meniru, memanipulasi, pengalamiahan dan artikulasi. Salah satu contoh aspek psikomotorik adalah kerja ilmiah.

Pembelajaran Fisika menekankan pada pemberian pengalaman langsung untuk mengembangkan kompetensi siswa. Pemberian pengalaman langsung ini dapat meningkatkan kemampuan siswa dalam melakukan suatu rangkaian metode ilmiah dan kerja ilmiah. Hal ini sesuai dengan tujuan pembelajaran Fisika yang diarahkan untuk membentuk sikap positif dan kerja ilmiah terhadap fisika (Aji \& Hudha, 2015).

Kemampuan kerja ilmiah dapat dikembangkan didalam pelajaran Fisika. Kerja ilmiah yang dikembangkan dalam pembelajaran fisika antara lain mendefinisikan masalah; menyatakan hipotesis; merancang percobaan; mengumpulkan dan menganalisis data; mengevaluasi atau menyampaikan hasil percobaan; dan menyimpulkan (Aji \& Hudha, 2016). Sehingga dalam proses pembelajaran ini dapat berjalan berjalan sesuai dengan tujuan peneliti, guru perlu menerapkan suatu model pembelajaran dan metode pembelajaran yang sesuai dimana dalam penelitian ini menggunakan model pembelajaran inkuiri yang melibatkan keatifan siswa secara penuh untuk meningkatkan kemampuan kerja ilmiah siswa 
yang masih rendah sehingga kerja ilmiah perlu dikembangkan untuk meminimalisir terjadi kesalahan konsep pada siswa (Hudha, 2014).

Model pembelajaran inkuiri adalah salah satu model pembelajaran yang tidak hanya memberdayakan sains sebagai produk tetapi juga mampu memberdayakan sains dan melibatkan siswa sebagai proses terutama demi peningkatan kemampuan siswa dalam berpikir (Kitot, Ahmad, \& Seman, 2010) dan membuat siswa lebih aktif dan kritis dalam kerja ilmiah (Mulder, Lazonder, \& De Jong, 2014). Inkuiri menekankan pada proses berpikir secara kritis dan analitis untuk mencari dan menemukan sendiri jawaban dari suatu masalah yang dipertanyakan. Selain itu pembelajaran inkuiri dapat meningkatkan pemahaman ilmu pengetahuan, kemampuan berpikir dalam kerja ilmiah, dan ketrampilan dalam memperoleh dan menganalisis informasi.

Dalam melakukan penilaian biasanya guru menggunakan lembar observasi atau evaluasi secara manual. Setelah evaluasi, peneliti dan observer harus melakukan perhitungan seluruh hasil penilaian kurang efisien karena masih berhitung secara manual. Oleh karena itu, dibutuhkan instrumen yang efektif dan efisien untuk memudahkan guru dalam penilaian kerja ilmiah. Penilaian yang dimaksud adalah menggunakan rubrik elektronik atau e-rubric (Mariani, Fey, \& Gloe, 2018)(Hudha et al., 2018)(Aji et al., 2018). Intrumen e-rubric ini adalah salah satu instrumen penilaian yang menjadi fokus penelitian. Rubrik elektronik atau e-rubric adalah alat penilaian alternatif yang membantu guru menentukan dan menjelaskan bagaimana siswa diharapkan untuk belajar dan memberikan kriteria kinerja yang akan dinilai dengan contoh ringkas dan spesifik.

Penilaian menggunakan e-rubric membantu siswa memantau kemajuan mereka secara cepat. E-rubric dalam penilaian formatif dapat meningkatkan efisiensi penilaian kerja ilmiah siswa. Rubrik penilaian ini juga berguna dalam membimbing proses pembelajaran berlangsung. Penilaian berbantuan e-rubric sebagai wujud kemajuan teknologi digunakan sebagai alat bantu dalam proses penilaian dalam pembelajaran.

\section{METODE}

Penelitian ini merupakan jenis penelitian deskriptif (Gallegos, Tesar, Connor, \& Martz, 2017). Penelitian ini dimaksudkan untuk mengamati serta memperoleh data atau informasi dalam mengumpulkan berbagai keterangan pada penggunaan model pembelajaran inkuiri berbantuan e-rubric kerja ilmiah siswa. Penelitian ini terdiri dari 4 pertemuan yang terbagi ke dalam 2 tahap, yaitu tahap I, dan tahap II. Pada Tahap I terdiri empat 2 kali pertemuan untuk menyampaikan materi pengertian gerak harmonik sederhana dan jenis gerak harmonik sederhana. Tahap II terdiri dari 2 pertemuan untuk menyampaikan materi besaran gerak harmonik sederhana. 
Desain penelitian ini dapat dilihat pada Tabel 1 berbantuan e-rubric, dan hasil penyebaran berikut angket. Teknik pengumpulan data yang

Tabel 1 Desain Penelitian digunakan dalam penelitian ini adalah

\begin{tabular}{|c|c|c|c|}
\hline Tahap & Materi & Pertemuan & Penilaiałhenggunakan \\
\hline & Pengertian & & angket. Teknik Analisis Data yang digunakan \\
\hline Tahap I & $\begin{array}{l}\text { harmonik sederhana } \\
\text { dan jenis gerak }\end{array}$ & 2 kali & $\begin{array}{l}\text { Porfotofodidalah nilai kerja ilmiah dan pelaksanaan } \\
\text { o/LKS pembelajaran. }\end{array}$ \\
\hline
\end{tabular}
serta besaran gerak harmonik sederhana

\section{HASIL DAN PEMBAHASAN}

\begin{tabular}{llll}
\hline & faktor -faktor yang & 2 kali & Porfotofoli. \\
Tahap & mempengaruhi & & o/LKS \\
II & periode bandul & & Kerja \\
& & & Ilmiah \\
\hline
\end{tabular}

Data kerja ilmiah siswa menggunakan pembelajaran Inkuiri

Penelitian ini dilaksanakan di SMAN 6

Malang. Subjek penelitiannya adalah siswa kelas $\mathrm{X}$ MIPA 1 dan 2 tahun pelajaran 2017/2018 dengan jumlah siswa setiap kelas 34 siswa. Data dan sumber data dapat dilihat pada Tabel 2, berikut.

Tabel 2 Data dan Sumber Data

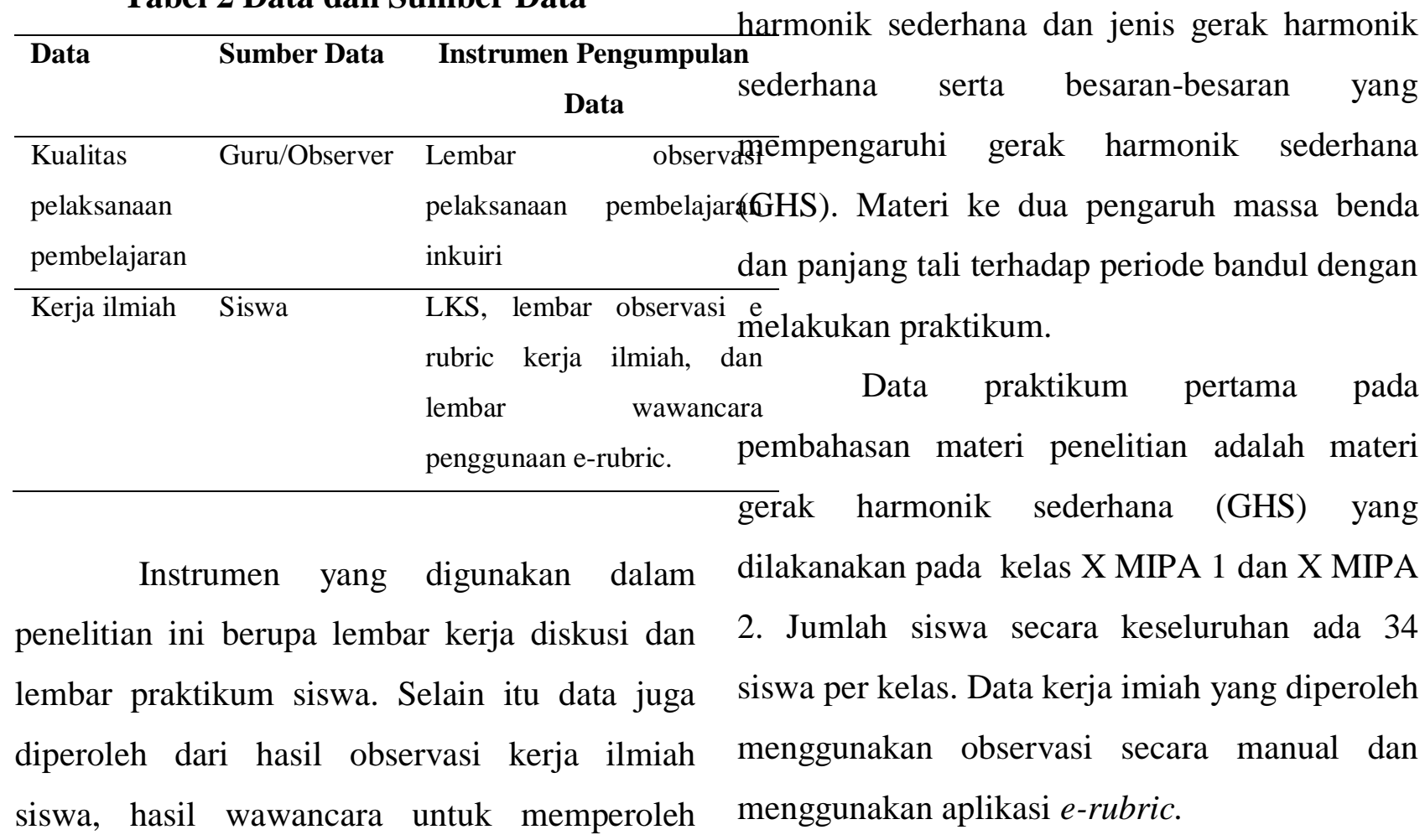
informasi tentang penggunaan penilaian 
Hasil observasi skor total e-rubric dan analisis skor penilaian tiap-tiap indikator kerja ilmiah siswa dengan menggunakan aplikasi $e$ rubric dapat dilihat pada Gambar 1.

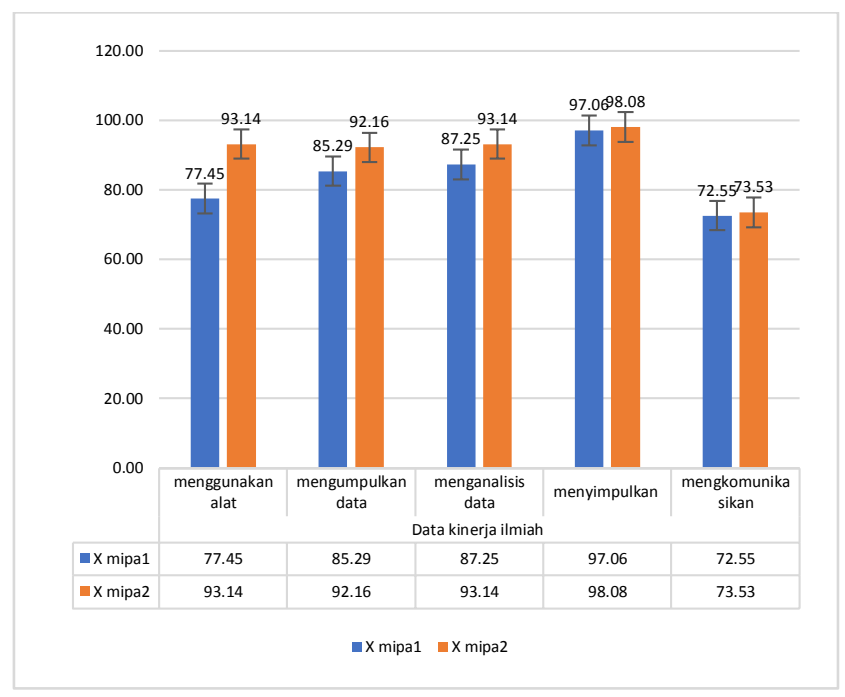

\section{Gambar 1. Data Kerja Ilmiah Siswa}

Dari penjelasan Gambar 1 diatas terkait data kerja ilmiah siswa sangat baik dari setiap indikator. Hal ini karena digunakan suatu model pembelajaran yang sesuai yang bisa membantu siswa bereksplorasi sendiri tanpa diminta seorang guru, serta suatu instrumen penilaian yang tepat. Karena jika dilihat selama ini, siswa tidak pernah mengetahui seccara langsung nilai kerja ilmiah mereka. Karena proses penilaian saat ini guru masih mengggunakan penilaian manual jadi dibutuhkan waktu yang cukup lama untuk memperoleh hasil kerja ilmiah siswa. Oleh karena itu digunakan penilain berbantuan aplikasi elektronik (e-rubric) yang mana proses penilaiannya sangat mudah dan cepat, sehingga dapat meningkatkan efektifitas kinerja pembelajaran khususnya dalam pembelajaran fisika.

\section{a. Angket Pengguna $e$-rubric}

Angket penggunaan e-rubric diberikan kepada 5 observer yang turut terlibat bersama peneliti selama pembelajaran dan yang menggunakan aplikasi e-rubric dalam menilai kerja imiah siswa. Pemberian angket ini bertujuan untuk mengetahui tanggapan mereka terhadap efektifitas penggunaan aplikasi $e$ rubric dalam menilai kerja ilmiah siswa. Adapun data hasil angket yang disajikan pada Gambar 2.

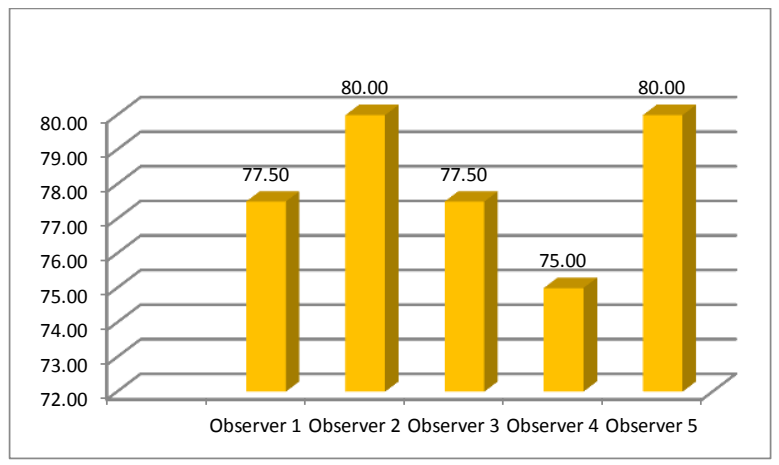

Gambar 2. Penggunaan Aplikasi e-rubric

\section{b. Wawancara}

Selain menggunakan angket, analisis penggunaan e-rubric juga dilakukan dengan menggunakan teknik wawancara. Untuk mengetahui efektifitas pengunaan aplikasi $e$ rubric peneliti melakukan wawancara kepada 5 orang guru yang mengunakan aplikasi e-rubric serta 5 orang guru yang tidak menggunakan aplikasi $e$-rubric dalam melaksanakan penilaian kerja ilmiah siswa. Adapun hasil rangkuman wawancara yang sudah dilaksakan berdasarkan pedoman wawancara.

\section{1) Pengguna $e$-rubric}

\section{Data Analisis Penggunaan $e$-rubric}


Berdasarkan rangkuman hasil penilaian menggunakan e-

wawancara, rata-rata jawaban tiap pertayaan dari masing-masing guru memiliki kesamaan. Adapun hasilnya yang dapat disajikan pada Tabel 3.

\section{Tabel 3. Hasil Rangkuman Wawancara}

Pengguna e-rubric

\begin{tabular}{|c|c|}
\hline Pertanyaan & Jawaban \\
\hline $\begin{array}{l}\text { Apakah sebelumnya pernah } \\
\text { menggunakan penilain seperti } \\
\text { ini? (e-rubric) }\end{array}$ & Belum \\
\hline $\begin{array}{l}\text { Pada saat diterapakan penilain } \\
\text { menggunakan } e \text {-rubric apakah } \\
\text { anda senang? Mengapa? }\end{array}$ & $\begin{array}{l}\text { Sangat senang } \\
\text { karena lebih praktis }\end{array}$ \\
\hline $\begin{array}{l}\text { Kesulitan apa saja yang kamu } \\
\text { alami selama menggunakan } \\
\text { penilaian } e \text {-rubric? Jelaskan! }\end{array}$ & $\begin{array}{lr}\text { Jika tidak memiliki } \\
\text { paketan } & \text { maka } \\
\text { aplikasi tidak bisa } \\
\text { digunakan, Harus } \\
\text { belajar lagi biar } \\
\text { tidak gaptek }\end{array}$ \\
\hline $\begin{array}{l}\text { Terhadap kesulitan yang } \\
\text { kamu alami tersebut apakah } \\
\text { guru sudah melakukan } \\
\text { perbaikan atau memberikan } \\
\text { solusi? }\end{array}$ & $\begin{array}{l}\text { Sudah tetapi perlu } \\
\text { untuk di pelajari lagi }\end{array}$ \\
\hline $\begin{array}{l}\text { Bagaimana hasil perbaikan } \\
\text { yang dilakukan guru tesebut? } \\
\text { Apakah cukup membantu } \\
\text { kamu? }\end{array}$ & $\begin{array}{l}\text { Lebih praktis dan } \\
\text { cukup membantu }\end{array}$ \\
\hline $\begin{array}{l}\text { Kemudahan apa saja yang } \\
\text { kamu alami selama } \\
\text { menggunakan penilaian } e \text { - } \\
\text { rubric? Jelaskan! }\end{array}$ & $\begin{array}{l}\text { waktu penilaian lebih } \\
\text { singkat }\end{array}$ \\
\hline $\begin{array}{l}\text { Bila dibandingkan dengan } \\
\text { penilaian biasa, menurut anda } \\
\text { apa kelebihan dan keunggulan } \\
\text { penilaian menggunakan dari } \\
\text { e-rubric? }\end{array}$ & $\begin{array}{l}\text { Modern, tidak gaptek, } \\
\text { praktis dan tidak } \\
\text { membutuhkan waktu } \\
\text { lama }\end{array}$ \\
\hline
\end{tabular}

rubric?

Bagaiman kesan anda setelah Sangat puas, praktis

dilaksanaannya penilain dan hematwaktu

dengan bantuan e-rubric?

\begin{tabular}{lll} 
Apa harapan atau perbaikan & Sebaiknya tiap \\
apa saja yang harus dilakukan & sekolah & bisa \\
guru berkaiatan dengan & menggunakannya. \\
penilaian yang menggunakan & \\
e-rubric ini? & \\
\hline
\end{tabular}

2) Tanpa e-rubric

Berdasarkan rangkuman hasil wawancara, rata-rata jawaban tiap pertayaan dari masing-masing guru memiliki kesamaan. Adapun hasilnya yang dapat disajikan pada Tabel 4

\section{Tabel 4. Hasil Rangkuman Wawancara} Tanpa Pengguna e-rubric

\begin{tabular}{lll}
\hline Pertanyaan & Jawaban \\
\hline Apakah sebelumnya kamu Pernah \\
pernah dinilai tentang kerja \\
ilmiah?
\end{tabular}

Apakah kamu tahu, guru Tahu
menggunakan instrumen yang
bagaimana untuk menilai
kerja imliah?

\begin{tabular}{l}
\hline Apakah kamu secara langsung \\
dapat mengetahui nilai kerja setelah bertanya \\
ilmiah yang kamu peroleh? \\
Jika kamu tahu, kamu \\
meperoleh nilai dari mana? \\
\hline Pernah kamu dinilai Pernah dan dan saat \\
menggunakan bantuan seperti tes ujian kompetensi \\
aplikasi komputer? Jika guru \\
pernah, pada saat kapan? \\
\hline Bagaimana kesulitan yang Lebih praktis \\
kamu alami berkaitan dengan
\end{tabular}


JIP, Vol.8, No. 2, Edisi Agustus 2018, Hal: 77-84 Muhammad Nur Hudha ${ }^{1}$, Sudi Dul Aji ${ }^{2}$, Yohana Susana Wolla Baga ${ }^{3}$, Arief Rahman Hakim ${ }^{4}$

\begin{tabular}{|c|c|}
\hline penilaian kerja ilmiah? & \\
\hline $\begin{array}{l}\text { Apa yang sudah dilakukan } \\
\text { guru dalam mengatasi } \\
\text { kesulitan yang kamu alami? }\end{array}$ & $\begin{array}{l}\text { Banyak dan perlu } \\
\text { untuk belajar lagi }\end{array}$ \\
\hline $\begin{array}{l}\text { Bagaimana dengan usaha } \\
\text { guru tersebut sudah dapat } \\
\text { mengatasi kesulitan anda? }\end{array}$ & Sudah \\
\hline $\begin{array}{l}\text { Apa kemudahan yang kamu } \\
\text { alami berkaitan dengan } \\
\text { penilaian kerja ilmiah. }\end{array}$ & Hemat waktu \\
\hline $\begin{array}{l}\text { Bagaiman harapan kamu } \\
\text { berkaitan dengan penilaian } \\
\text { yang digunakan guru } \\
\text { kedepannya terutama } \\
\text { penilaian tentang kerja ilmiah } \\
\text { (guru bisa menyinggung } e- \\
\text { rubric) }\end{array}$ & $\begin{array}{l}\text { Harus belajar lagi } \\
\text { dan berusaha }\end{array}$ \\
\hline $\begin{array}{l}\text { Apakah sebelumnya kamu } \\
\text { pernah mendengar penilaian } \\
\text { menggunakan e-rubric? Jika } \\
\text { ia, dari mana kamu } \\
\text { mendengarnya? }\end{array}$ & $\begin{array}{l}\text { Pernah } \\
\text { pertemuan } \\
\text { mapel IPA }\end{array}$ \\
\hline $\begin{array}{l}\text { Jika di kelas kamu suatu saat } \\
\text { nanti menggunakan penilaian } \\
\text { berbantuan e-rubric, apakah } \\
\text { anda setuju? }\end{array}$ & Sangat setuju \\
\hline
\end{tabular}

Berdasarkan hasil wawancara dengan pengguna e-rubric, diketahui bahwa sebagian besar guru merasa puas dengan adanya apalikasi e-rubric dalam menilai kemampuan kerja ilmiah siswa. Kepuasaan ini dikarenakan aplikasi $e$ rubric mempermudah proses penilaian, menghemat waktu penilaian serta tingkat ketercapaian kemampuan kerja ilmiah siswa dapat diketahui dengan cepat. Dengan kemudahan dan efektiftas penggunaannya maka aplikasi e-rubric direkomendasikan sebagai instrument alternative untuk menilai kemampuan kerja ilmiah siswa serta dengan adanya penilaian aplikasi e-rubric dengan digunakan model yang sesuai dapat meningkatkan efektifitas kinerja pembelajaran

Berbeda dengan pengguna aplikasi $e$ rubric, hasil rangkuman wawancara dengan observer tanpa menggunakan aplikasi e-rubric justru mengalami kesulitan. Mereka terbiasa dengan menggunakan teknik manual sehingga memakan waktu yang cukup lama untuk mengetahui tingkat ketercapaian kemampuan kerja ilmiah siswa (Hudha et al., 2018)(Aji et al., 2018). Selain itu, mereka juga belum mengetahui akan adanya instrument lain yang dapat memudahkan penilaian seperti penggunaan aplikasi $e$-rubric.

\section{SIMPULAN}

Pembelajaran fisika menggunakan model pembelajaran inkuiri berbantuan aplikasi e-rubric sangat efektif dalam menilai kerja ilmiah siswa selama proses pembelajaran berlangsung. Dengan menggunakan model pembelajaran dan instrumen yang tepat dapat meningkatkan efektifitas penilaian kerja ilmiah dalam proses pembelajaran

\section{DAFTAR PUSTAKA}

Aji, S. D., \& Hudha, M. N. (2013). Kerja Ilmiah Siswa Smp Dan Sma Melalui Authentic Problem Based Learning (Apbl). Jurnal Inspirasi Pendidikan Universitas Kanjuruhan Malang, 6(1), 574-581. 
JIP, Vol.8, No. 2, Edisi Agustus 2018, Hal: 77-84 Muhammad Nur Hudha ${ }^{1}$, Sudi Dul Aji ${ }^{2}$, Yohana Susana Wolla Baga ${ }^{3}$, Arief Rahman Hakim ${ }^{4}$

Retrieved from ejournal.unikama.ac.id

Aji, S. D., \& Hudha, M. N. (2015). Dampak

PBL Terhadap Kerja Ilmiah Mahasiswa pada Perkuliahan Pengembangan Media Pembelajaran. Jurnal Inspirasi Pendidikan, 5(2), 708-714.

Aji, S. D., Hudha, M. N., Huda, C., NANDIYANTO, A. B. D., \& ABDULLAH, A. G. (2018). the Improvement of Learning Effectiveness in the Lesson Study By Using E-Rubric. Journal of Engineering Science and Technology, 13(5), 1181-1189.

Dickinson, P., \& Adams, J. (2017). Values in evaluation - The use of rubrics. Evaluation and Program Planning, 65, 113-116. https://doi.org/10.1016/j.evalprogplan.2017 .07 .005

Gallegos, C., Tesar, A. J., Connor, K., \& Martz, K. (2017). The use of a game-based learning platform to engage nursing students: A descriptive, qualitative study. Nurse Education in Practice, 27, 101-106. https://doi.org/10.1016/j.nepr.2017.08.019 Hudha, M. N., Aji, S. D., \& Huda, C. (2018). ERubric: Scientific Work Based on Android for Experimental Physic. IOP Conference Series: Materials Science and Engineering, 288(1). https://doi.org/10.1088/1757899X/288/1/012100

Kitot, A. K. A., Ahmad, A. R., \& Seman, A. A. (2010). The effectiveness of inquiry teaching in enhancing students' critical thinking. Procedia - Social and Behavioral Sciences, 7(C), 264-273. https://doi.org/10.1016/j.sbspro.2010.10.03 7

Mariani, B., Fey, M. K., \& Gloe, D. (2018). The Simulation Research Rubric: A Pilot Study Evaluating Published Simulation Studies. Clinical Simulation in Nursing, 22, 1-4. https://doi.org/10.1016/j.ecns.2018.06.003

Menéndez-Varela, J. L., \& Gregori-Giralt, E. (2018). Rubrics for developing students' professional judgement: A study of sustainable assessment in arts education. Studies in Educational Evaluation, 58(June), 70-79. https://doi.org/10.1016/j.stueduc.2018.06.0 01

Mulder, Y. G., Lazonder, A. W., \& De Jong, T. (2014). Using heuristic worked examples to promote inquiry-based learning. Learning and Instruction, 29, 56-64. https://doi.org/10.1016/j.learninstruc.2013. 08.001

Pratama, Nurris Septa; Istiyono, E. (2015).

Studi Pelaksanaan Pembelajaran Fisika Berbasis Higher Order Thinking (HOTS)

Pada Kelas X Di SMA Negeri Kota Yogyakarta. Prosiding Seminar Nasional Fisika Da n Pendidikan Fisika (SNFPF), 6, 9. https://doi.org/ISSN : 2302-7827 